\title{
BEHAVIORAL MODIFICATIONS RELATED TO CONSUMPTION OF A "SOFT" ADAPTOGEN, BEE HONEY, BY RATS
}

Received January 22, 2011.

\begin{abstract}
Modifications of neurobehavioral activities related to single episodes of consumption of different doses of bee honey were examined in rats under conditions of the hole-board (HB) test (to evaluate the level of anxiety) and open-field (OF) test (where the intensities of locomotion, rearing, and grooming were measured). Animals of all subgroups had free access to normal saline, while rats of the three experimental subgroups consumed bee honey in the doses of $0.5,1.0$, and $2.0 \mathrm{~g}$ per $1 \mathrm{~kg}$ body mass (in the form of 10,20 , and $40 \%$ solutions, respectively). Among the doses tested, only higher ones induced considerable changes in the behavioral indices. The highest dose $(2.0 \mathrm{~g} / \mathrm{kg})$ provided a more than twofold increase in the number of examined holes in the HB test; in the OF test, it also increased the numbers of crossed squares, rearings and grooming episodes by 30,37 , and $164 \%$, respectively. Thus, our experiments demonstrated rather significant ability of the natural product tested to relieve anxiety and intensify motor, research/orientational, and grooming aspects of behavior even upon single acts of consumption. Possible neurophysiological mechanisms underlying the behavioral modifications observed are discussed.
\end{abstract}

Keywords: behavioral activities, hole-board test, open-field test, anxiety, bee honey.

\section{INTRODUCTION}

Bee honey is a generally known and extensively used food product, a sweet syrupy substance produced by the honey bee (genus Apis) from flower nectars. Honey gets its sweetness from monosaccharides, fructose and glucose; the sweetness of honey is approximately the same as that of granulated sugar $[1,2]$. Honey contains noticeable amounts of vitally necessary microelements, such as copper, zinc, iron, and manganese; vitamins B2, B5, B6, B9, and C are also present in honey [3]. During the entire history of the mankind, bee honey was for thousands and thousands of years and is at present used as an attractive and valuable food product, and its energy-restoring and curative capabilities are known from prehistorical times. Due to its nonspecific but rather well-expressed positive effects on the state of the human organism, bee honey can be qualified, according to the to-day terminology, as a "soft" adaptogen.

\footnotetext{
${ }^{1}$ Department of Physiology, College of Health Sciences, Ladoke Akintola University of Technology, Ogbomoso, Nigeria.

${ }^{2}$ Department of Physiology, University of Benin, Edo State, Benin, Nigeria. Correspondence should be addressed to O. A. Oyekunle (e-mail: pintos4live@yahoo.com).
}

Despite the fact that "everyday" diet-related and strictly medical uses of honey and its folkloric applications are rather extensive, the effects of this agent on various aspects of behavior practically have not been quantitatively estimated. This question may be adequately resolved in the corresponding experiments on animals. This is why we examined the ability of this natural product to influence the anxiety level in a novel environment and to modify different types of activity in the open-field (OF) test.

\section{METHODS}

Bee honey was produced by the apiary of the Faculty of Agricultural Sciences, Ladoke Akintola University of Technology, Ogbomoso (Nigeria). Honey samples were dissolved in distilled water to 10,20 , and $40 \%$ concentrations and given to animals in the dose of $0.5 \mathrm{ml} / 100 \mathrm{~g}$ body mass; thus, doses of pure honey in the three experimental groups (see below) were 0.5 , 1.0 , and $2.0 \mathrm{~g}$ per $1 \mathrm{~kg}$ body mass.

Animals. Forty Wistar rats of both sexes (females, nonpregnant) weighing 100 to $120 \mathrm{~g}$ were used. All animals were kept under standard vivarium conditions 
(preclinical animal house of Ladoke Akintola University of Technology) at $23 \pm 2{ }^{\circ} \mathrm{C}$ and $12 \mathrm{~h} \mathrm{light/}$ dark cycle. The animals were fed with standard rat pellet food, and normal saline for drinking was provided ad libitum. They were acclimatized in the laboratory for at least 1 week before the experimental session. All experimental procedures were done following the experimental guidelines of the Institutional Animal Ethics Committee (IAEC).

Twenty rats were examined under conditions of the hole-board (HB) test, while other 20 rats were subjected to the OF test. Each of the above groups was subdivided into four subgroups, five rats in each. Subgroup 1 served as the control, while experimental animal subgroups 2-4 consumed the above-mentioned doses of honey.

HB Test. In this procedure [4], $1 \mathrm{~h}$ after administration of bee honey in different doses, the animals were placed for 6 min on a $40 \times 40 \mathrm{~cm}$ board with 16 holes symmetrically distributed in 4 rows. The numbers of times the animal dipped its head into the hole within a 6-min-long observation period in the novel environment were measured, and the mean numbers of head dips were calculated.

OF Test. For each test session, rats were allowed to explore the testing environment in a quiet wellventilated room for at least $30 \mathrm{~min}$. Spontaneous behavioral activity was monitored for a 30-min-long observation period under modified OF conditions, as was described by Eckeli et al. [5]. Briefly, the OF structure consisted of a $60 \times 60 \mathrm{~cm}$ rectangular arena composed of a hard board floor with surrounding walls made of white painted wood. The floor was divided by a permanent red marker into squares of $4.2 \times 4.2 \mathrm{~cm}$. Each rat was introduced into the arena $1 \mathrm{~h}$ after oral administration of bee honey. The locomotor activity was evaluated by counting the number of floor square units crossed with all paws. The grooming activity was characterized by the number of episodes of licking the body and pubis with mouth and face washing actions. Research/orientational behavior was evaluated by counting the number of stands of the animal on its hindlimbs against the wall of the observation cage or in the air.

Before introducing each animal into the arena, the latter (similarly to the HB plate) was thoroughly cleaned with methylated spirit to eliminate possible bias due the odour that could be left by previous individuals.

Statistical Analysis of Numerical Data. Results of observations were expressed as means \pm s.e.m.
The significance of differences between subgroups was estimated using one-way analysis of variance (ANOVA) followed by post-hoc Dunnett test. In all observations, the cases of statistical significance were considered at $P<0.05$.

\section{RESULTS}

Observation of the HB test showed that consumption of the two higher doses of honey used resulted in significant increments in the mean number of head dips performed by the animals put in an unknown environment under conditions of this test. In group 3 (experimental; $1.0 \mathrm{~g}$ of honey per $1 \mathrm{~kg}$ body mass), this increase was $47 \%(P<0.05)$, as compared with the respective index in the control group 1 , while $2.0 \mathrm{~g} / \mathrm{kg}$ (group 4) increased the frequency of manifestations of research behavior more than two times (by $130 \%$, $P<0.01)$. The smallest dose of honey used $(0.5 \mathrm{~g} / \mathrm{kg})$ induced no changes in the above type of behavior, as compared with the control (Fig. 1).

Under conditions of the OF test, honey doses of 1.0 and $2.0 \mathrm{~g} / \mathrm{kg}$ induced nearly similar modifications of locomotor activity increasing the intensity of the latter by 25 and $35 \%$, respectively $(P<0.05$ in both cases). The mean intensity of locomotion in group 2 (honey dose $0.5 \mathrm{~g} / \mathrm{kg}$ ) appeared to be even somewhat

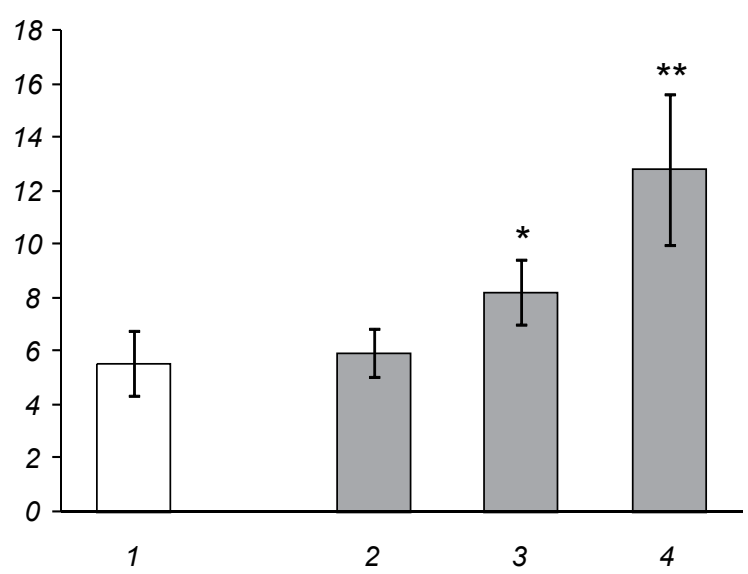

Fig. 1. Effects of consumption of bee honey on exploratory behavior of rats under conditions of the hole-board test. Diagram of means \pm \pm s.e.m. of the numbers of head dips during a 6-min-long observation period $1 \mathrm{~h}$ after oral administrations of $0.5,1.0$, and $2.0 \mathrm{~g} / \mathrm{kg}$ body mass of honey (groups 2-4, respectively; 1 is the control group). One and two asterisks show cases of significant differences from the control with $P<0.05$ and $P<0.01$, respectively.

Р и с. 1. Вплив споживання бджолиного меду на дослідницьку поведінку щурів в умовах норкового тесту. 
$A$
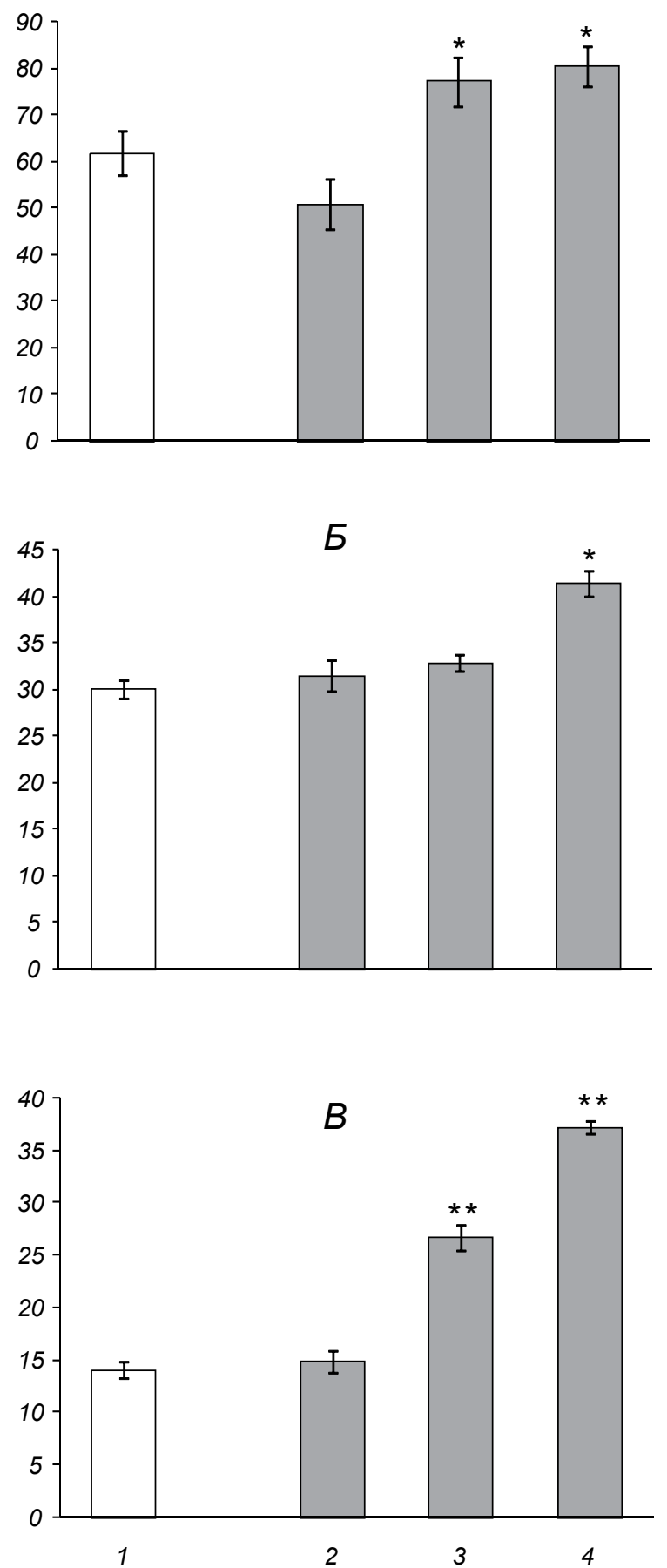

Fig. 2. Effects of consumption of bee honey on behavioral indices in rats under conditions of the open-field test. A-C) Diagrams of means \pm \pm s.e.m. of the numbers of crossed squares (locomotor activity, A), rearings (research activity, B), and episodes of grooming (C) during a 30-min-long observation period $1 \mathrm{~h}$ after oral administration of different doses of honey. Other designations are the same as in Fig. 1.

P и с. 2. Вплив споживання бджолиного меду на показники поведінки щурів в умовах відкритого поля. lower (insignificantly) than this type of activity in the control group 1 (Fig. 2A).

Manifestations of the exploratory activity in the OF (rearings, stands) underwent practically no changes after administrations of honey in the two smaller doses $(0.5$ and $1.0 \mathrm{~g} / \mathrm{kg})$; only the highest dose $(2.0 \mathrm{~g} / \mathrm{kg})$ produced a significant $(37 \%, P<0.05)$ increment when compared with the control (Fig. 2B).

The most intense modifications after consumption of bee honey were found in grooming behavior. Small doses $(0.5 \mathrm{~g} / \mathrm{kg})$ were ineffective, while $1.0 \mathrm{~g} / \mathrm{kg}$ provided a nearly twofold (by $90 \%$ ) increase in the intensity of grooming activities. The highest dose $(2.0 \mathrm{~g} / \mathrm{kg})$ intensified this type of behavior more than two and half times (by $164 \% ; P<0.01$ ), as compared with the respective index in the control (group 1) (Fig. 2C).

\section{DISCUSSION}

The main finding made in our study can be summarized as follows: Even single episodes of consumption of bee honey by experimental animals (rats) lead to readily observable modifications of their behavior under conditions of the HB and OF tests. These effects are clearly dose-dependent; they are manifested only at sufficient doses of honey. Naturally, we discuss in our communication neither such effects of bee honey and accompanying products (e.g., pollen) as their antibacterial, antioxidant, etc. activities wellknown from reports on "official" medicine usage and folkloric applications [6,7] nor effects of longlasting systematic consumption of honey, where its adaptogenic properties can be most clearly expressed.

Undoubtedly, rapid supply of the organism with significant amounts of easily accessible substrates for energetic metabolism (glucose and fructose) seems to be a first-order factor underlying the effects on various behavioral manifestations (general increase in the intensity of the latter). At the same time, it is likely that a rapid rise in the glucose level in the blood cannot per se be exclusively responsible for such deep changes in the indices characterizing anxiety in the $\mathrm{HB}$ test and a number of behavioral indices in the OF test. An assumption that the above rise is accompanied by significant shifts in the state of a few cerebral neuromodulatory systems significantly influencing the behavioral characteristics seems to be rather logical.

A quite obvious anxiolytic effect of bee honey allows us to suppose that it is related to a rapid increase 
in the level of serotonin (5-HT) in various cerebral structures. The state of the cerebral serotonergic system was convincingly shown to closely correlate with the level of anxiety in humans and different animals [8, 9]. Despite a great diversity of the types and subtypes of 5-HT receptors in the CNS [10] and information that selective modulation of different groups of these receptors specifically influences anxiety disorders [11], a global effect of increases in the 5-HT level in the CNS leads to a decrease in the level of anxiety. In contrast, exhaustion of the amount of 5-HT, which can be induced by different pharmacological and nonpharmacological influences, results in a rise in the anxiety level. If this state is prolonged, such a situation can evoke the development of anxious depression $[5,12]$.

In our experiments, rats, after consumption of honey in a sufficient dose, significantly increased their research activity in the $\mathrm{HB}$ test much more frequently dipping their heads in unexplored holes in the behaviorally novel environment. This anxiolytic effects is quite comparable with a change in the research rearing activity under conditions of the OF test.

It also seems probable that some other cerebral modulatory systems are involved in modifications of rat behavior related to consumption of honey. In particular, this is the mesolimbic dopaminergic system. As was mentioned, grooming activity underwent the most intense modulation after honey administration, as compared with other types of behavior in the OF test. As was shown, selective agonists of dopamine $\mathrm{D}_{1}$ and $\mathrm{D}_{5}$ receptors elicit intensification of grooming behavior, while $\mathrm{D}_{2}$ receptor agonists somewhat reduce this type of behavioral activity $[13,14]$. Thus, a selective, to a certain extent, action of a rapid rise in the glucose level (related to consumption of honey) on certain types of dopamine receptors should be supposed. Naturally, an attempt to answer the respective question needs special investigation. The same can be noted with respect to the question whether certain specificity of the composition of bee honey (as compared, e.g., with "pure" sugar) plays a role in the action of this product on functioning of the cerebral modulatory systems.

Therefore, our observations demonstrated that bee honey in sufficiently high amounts possesses a significant modulatory behavioral potential manifested in the case of single consumption. Bee honey ameliorates anxious behavior (acting as an anxiolytic) and provides a noticeable general stimulating effect on the CNS (an antidepressant action). These behavioral shifts probably determine, to a considerable extent, the extensively known action of bee honey as a "soft" adaptogen under conditions of its systematic consumption. Our observations confirm well-known ideas on the expedience of the use of honey as a supplement in special diets for subjects suffering from mood disorders. At the same time, the mechanisms underlying the action of this product on cerebral modulatory systems (such an action, according to our data, seems to be rather probable) may need special thorough investigation.

Acknowledgment. The authors are sincerely grateful to Mr. E. O. Akinbolusere, chief technologist, the Department of Physiology, for his technical assistance.

О. А. Ойекунле, Т. П. Огундеджи ${ }^{l}$, A. К. Окойє $\epsilon^{2}$

МОДИФІКАЦІЇ ПОВЕДІНКИ, ПОВ' ЯЗАНІ ЗІ СПОЖИВАННЯМ ЩУРАМИ “М' ЯКОГО” АДАПТОГЕНУ БДЖОЛИНОГО МЕДУ

${ }^{1}$ Коледж медичних наук, Технологічний університет Ладоке Акінтола, Огбомозо (Нігерія).

2 Університет Беніна, Бенін (Нігерія).

P е 3 ю м е

Модифікації нейроповедінкової активності, пов'язані з поодинокими епізодами споживання бджолиного меду в різних дозах, були вивчені у щурів в умовах норкового тесту (визначення рівня тривожності) і тесту відкритого поля (вимірювання кількості епізодів локомоції, вертикальних стійок і грумінгу). Тварини контрольних підгруп мали вільний доступ до фізіологічного розчину, тоді як щури трьох експериментальних підгруп споживали мед у дозах $0.5,0.1$ та 2.0 г з розрахунку на 1 кг маси тіла (у вигляді 10, 20 й $40 \%$-вого розчинів відповідно). Значні зміни поведінкових показників виникали тільки при вищих тестованих дозах. Максимальна доза (2.0 г/кг) зумовлювала більше ніж дворазове збільшення кількості досліджених отворів у норковому тесті; в умовах тесту відкритого поля при такій дозі також збільшувалася кількість пересічень щурами квадратів, вертикальних стійок та епізодів грумінгу відповідно на 30, 37 i 164 \%. Отже, результати наших експериментів показали, що тестований натуральний продукт (бджолиний мед) виявляє значну здатність знижувати рівень тривожності та посилювати моторні, дослідницькі/орієнтаційні та грумінгові аспекти поведінки навіть у разі поодиноких актів його споживання. Обговорюються можливі нейрофізіологічні механізми, що лежать в основі поведінкових модифікацій, спостережуваних в експерименті. 


\section{REFERENCES}

1. National Honey Board, Carbohydrate and the Sweetness of Honey (last accessed May 5, 2008 at http//www.honey.com).

2. Oregon State University Sugar Sweetness (last accessed May 5, 2008 at http//www.food.oregonstate.edu/sugar).

3. USDA Nutrient Data Laboratory Honey (last accessed August 24, 2007 at http//www.nal.usda.gov/fnic/food).

4. J. R. Boissier and P. Simon. "L' utilization du test de la traction (Test de JULOU-COURVOISIER) pour l'etude des psycholeptiques," Therapie, 15, 1170-1174 (1960).

5. A. L. Eckeli, F. Dach, and A. L. Rodrigues, "Acute treatments with GMP produce antidepressant-like effects in mice," NeuroReport, 11, No. 9, 1839-1843 (2000).

6. P. C. Molan, "Honey for treatment of infections," The New Zealand Bee Keeper, 216, 19-20 (1992).

7. E. Sofic, A. Rustembegovic, G. Kroyer, and G. Cao, "Serum antioxidant capacity in neurological, psychiatric, renal diseases and cardiomyopathy," J. Neural. Transm., 109, 711719 (2002).
8. S. A. Montegomery, "Clinical significance of 5-HT reuptake inhibitors," Psychopharmacology, 6, 53-58 (1991).

9. G. Griebel, J. L. Moreau, F. Jenck, et al., "Acute and chronic treatment with 5-TH reuptake inhibitors differentially modulate emotional responses in anxiety models in rodents," Psychopharmacology, 113, 463-470 (1994).

10. I. Lucki, "Serotonin receptor specificity in anxiety disorders," J. Clin. Psychiat. 57, Suppl. 6, 5-10 (1996).

11. S. D. Iversen, "5-HT and anxiety," Neuropharmacology, 23, 1553-1560 (1984).

12. R. G. Lister, "The use of a plus-maze to measure anxiety in the mouse," Psychopharmacology, 92, No. 2, 180-185 (1987).

13. M. Briley, P. Chopin, and C. Moret, "Effect of serotonergic lesion on anxious behavior measured in the elevated plus-maze test in the rat," Psychopharmacology, 101, 187-189 (1990).

14. F. Ferrari, F. Pelloni, and D. Giuliani, "Suppressive effect of the dopamine $\mathrm{D}_{2}$ receptor against 5-HT on rat grooming," Eur. J. Pharmacol., 216, 345-350 (1992). 